\section{Teaching Vocabulary Using Blended Learning Method}

1 Maya Masita

1 Universitas Muhammadiyah Bulukumba, Indonesia

\begin{abstract}
This is a case study aimed at describing teaching vocabulary based blended learning method. There were 30 students involved in this study. The data were taken using mixed methods by giving an interview and observation. The findings of this study were analyzed using triangulation analysis. The results of this study showed that: 1) vocabulary teaching model based blended learning method create an interactive teaching and learning atmosphere, 2) the students are not familiar with the learning application, so they found difficulties using smartphone in accessing learning application, 3) the internet connection is unstable, so the teacher should prepare another activity, 4) the selection of learning applications that suitable with students need to make the teaching and learning activities more fun, easy to understand, and keep following the development of teaching and learning methods.
\end{abstract}

Keywords

teaching model teaching vocabulary blended learning

\section{Ethical Lingua}

Vol. 7, No. 1, 2020

ISSN 2355-3448 (Print)

ISSN 2540-9190 (Online)

Corresponding Email

Maya Masita

mayamasitahir@gmail.com

Article's History

Submitted 26 Dec 2019

Revised 11 April 2020

Accepted 11 April 2020

DOI

10.30605/25409190.143

Copyright $(2020$

The Author(s)

This article is licensed under CC BY-NC-SA 4.0 License 


\section{Teaching Vocabulary Using Blended Learning Method}

Vocabulary is one of the important elements in learning English. Without knowledge of vocabulary, students are not able to speak well in English. The students cannot deliver or receive messages effectively. Vocabulary is an important element in language learning; since it supports the four language skills. By learning vocabulary, the students will be able to know the meaning and the form of the word. Vocabulary is a list of words, and every word has its own meaning. Each word has certain meaningful communication. Vocabulary is essential for language learners to master as it helps form sentences and express themselves in meaningful ways. It has been proved to be powerfully related to $L 2$ acquisition with many studies as well. Teaching vocabulary has an important role in language acquisition.

The mastery of vocabulary will help the students to master the language. Wallace (1982) explains that teaching vocabulary should consider several factors. First, in the teaching and learning process, the teacher has to be clear about his aims and deciding the words that should be mastered by his students. Second, the teacher has to decide the quantity of vocabulary to be learned, as the number of new words in a lesson is crucial. The actual number of factors depends on varying from class to class and learner. If there are too many new words, the learners may become confused, discouraged, and frustrated. Third, the teacher has to choose the words needed by his students in communication. The students should be put in a situation where they have to communicate and get the words they need. Fourth, the teacher should give so much practice and repetition so that the students master the target words well. He also should allow the students to use the words in writing or in speaking. Fifth, the teacher should present the target words in such a way that their meanings are clear and unambiguous. Therefore, the new words should be presented in contexts, not in isolation. Sixth, the teacher should explain to the students that they have to use the words appropriately. The use of words depends on the situation in which they are speaking and depends on the person to whom they are speaking. Those principles of teaching vocabulary are to reach the target language.

From the explanation above, the teachers have to know the different kinds of vocabulary, and also understanding the factors is very important for the teacher before teaching vocabulary. Sahraini (2015) explains that before conducting a process of teaching and learning in the classroom, a teacher should prepare a model of teaching designed based on the curriculum framework and the principles of learning and teaching to guide learning, teaching and assessment for students to achieve the outcomes. The teaching and learning model is a guide to teach students the techniques of creative and productive thinking. A teaching model is a specific approach to instruction that have three main points: 1) goals, designed to help students develop critical- thinking abilities and acquire deep understanding of specific forms of content; 2) phases, it is include a series of steps often referred to as "phases" that are intended to help students reach specific learning goals; 3) foundations, the following standards should be considered, differences, and how they learn.

A model of teaching and learning is a critical instructional planning and delivery to help educators: 1) develop highly tuned and more varied professional repertoires; 2) allow them 
to reach larger numbers for students more effectively; 3 ) create either more uniform, or varied, or effective instructional events, guided by targeted subjects, content, or processes; 4) understand curricular better, especially as different models can be matched specifically both learning outcomes and/or targeted learning populations; 5) gain needed insights into why some methods work with some learners. While others do not; 6) radically modify or redesign existing methods of teaching and instructional delivery so that emerging or modified instructional techniques may better meet the needs of tomorrow's students (Sahraini, 2015).

There are two approaches of teaching model: teacher-centered and student- centered. This study used a student-centered model, In this approach, the teacher is still the authority figure, but the student plays active role in what is learned. The idea is the teacher will advise and guide the students down a learning path. Assessment involves informal and formal methods - group projects, portfolios, and class participation. The teacher continues to see a student's learning process throughout the lesson. There are two subcategories in this approach; they are inquiry-based learning and cooperative learning. Inquiry-Based Learning, this teaching style focused on students in exploring and participating in the learning process. The teacher is guidance in giving the students advice and supporting their efforts. Students are expected to participate and play an active role in their learning. The characteristics of these models are: 1) Facilitator, 2) Personal Model, and 3) Delegator.

Sahraini (2015) claims that in designing a model of teaching and learning of English vocabulary through interactive activities, an English teacher is expected to make the students enjoyable and interested in studying English. The teacher must be also creative in using some appropriate approaches, techniques, and games in the process of teaching and learning.

Teaching vocabulary is challenging in Indonesia, as we know English is not our first language. Teaching vocabulary in Society Era 5.0 can be done in various ways. Technology has supported and brought positive impact in teaching and learning process. One method that can be used in this era is a blended learning method. This method combined online digital media with traditional classroom methods. Blended learning is the use of two or more distinct methods of training. This may include combinations such as face to face classroom combine with online instruction, blending online lesson with e-learning activities.

Indah (2015) found out that integrated computer-assisted media (ICAM) can improve the vocabulary achievement of the students. ICAM is more fun, enjoyable, effective, and efficient in teaching English vocabulary, especially unfamiliar words than single media. Albrecht (2006) claims that blended learning is bringing together Face-to-Face classroom instruction with web-based activity. Similarly, Bersin (2004) affirms that blended learning is the combination of different training media (technologies, activities, and types of events) to create an optimum training program for a specific audience. Besides, as stated by Bender cited in Ochoa Alpala \& Roberto Flórez (2011), in using blended learning, the students become more active in their learning, feeling more technologically empowered, and able to learn anywhere and anytime in the manner that best suits their lifestyle.

Morris (2010) stated that Blended learning is progressively becoming a prospect for higher education students. It permits the improvement of face-to-face interface between teachers and learners, using the internet or computer-based techniques. According to (Mantyla, 2001) blended learning is the use of two or more presentation and distribution procedures for improving both the content and the learners' experience. Blended learning uses different 
approaches, comprising print-based materials, instructor-led training, and web-based training, for example. In a positive mode, it can be assumed that blended learning has always occurred, since the appearance of the first learning technologies, teachers and learners have always attempted to find an active compromise between sessions necessitating these skills and more classical face-to-face teaching sittings.

Alpala \& Flórez (2011) analyze blended learning in the teaching of English as a Foreign Language: an educational challenge. In this study, the conclusion was an EFL Blended Course requires a carefully organized methodology. Therefore, students must be trained first in how to use the technological devices and then be guided through the EFL process and all the virtual and printed tools they have available to improve their English command. It is also important to train them on how to use these tools strategically since it is noticeable that some students do not know how to use them effectively. For this reason, the EFL teacher must clearly explain every stage and characteristic of the virtual platform and how it works.

Pardede (2012) claims that blended learning provides EFL students with recording devices, video players, newspapers, and language laboratories. A variety of activity types with group work and pair work, collaborative learning and independent learning could be employed to engage the learners in communicative language practice. Beside, the inclusion of the online element in blended learning also enables the use of the foreign language in real communicative acts (through forums, chats, emails, etc.) and provides students with authentic learning material. It allows for the diversity of EFL students' learning styles to be catered for, perhaps more easily than in face-to-face settings. Vasbieva, Klimova, Agibalova, Karzhanova, \& Bírová (2016) investigated the effects of the blended learning approach to teaching English vocabulary to ESL learners. The results of this study is blended learning produced a positive effect on the ESL learners' test results. Sherli, Talis, Akib, \& Baso (2018) states that the students enjoy the learning process when the lecturer implementing blended learning method. Besides that, the benefit of blended learning method for the students made them more interested in learning. It is also can be seen from the students' questionnaire that they got some benefits from the method; the students become more active and responsible for learning.

The previous study showed the positive impact of teaching vocabulary using blended learning method, in contrast in this study give a model of teaching vocabulary using blended learning method for the first year students of English Language Learner in Higher Education. The differences between this study with the previous study are the previous study only analyze teaching and method. In contrast, this study gives a model of teaching vocabulary based blended learning method. Therefore, the question raised in this study is: What is the design of vocabulary teaching model based blended learning method?

\section{Method}

This research is a case study aimed at describing a teaching vocabulary based blended learning method. According to Gay \& Mills (2012) the purpose of the case study is to produce detailed descriptions of the phenomenon. The researcher attempts to depict an occurrence and conceptualize it. There were 30 students involved in this study. The data were taken using mixed methods by giving an interview and observation during the teaching and learning process. The findings of this study were analyzed the quan-qual model, also 
known as the triangulation mixed methods design, quantitative and qualitative data are equally weighted and collected concurrently throughout the same study (Gay \& Mills, 2012).

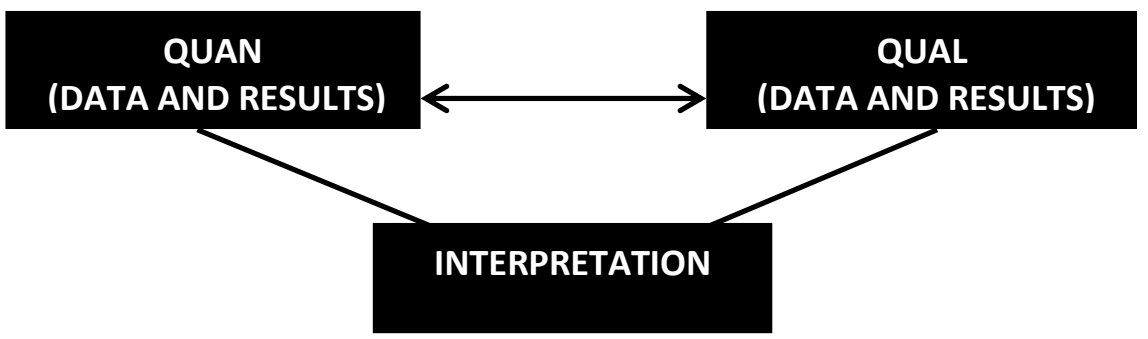

Figure 1. Triangulation Mixed Methods Design (Gay, Mills, W.A.P (2012))

This study started in August 2019 and finished in November 2019. This study takes place in the first year of English Language Learner class of English Education Program at Universitas Muhammadiyah Bulukumba. One lecturer with one class is selected. The selected class is vocabulary class taught by using blended learning method. This method is designed by the teacher.

\section{Results}

Gay \& Mills (2012) claims that observation allows the researchers to formulate their own version of what is occurring, independent of participants. The inclusion of selected observations in a researcher's report provides a more complete description of phenomena than would be possible by just referring to interview statements or documents.

Table 1. Observation Result

\begin{tabular}{llllr}
\hline No. & Observation Indicator & $\begin{array}{l}\text { Number of } \\
\text { Students }\end{array}$ & $\begin{array}{l}\text { Total Number } \\
\text { of Student }\end{array}$ & Percentage \\
\hline 1. & Pay attention & 25 & 30 & $83 \%$ \\
2. & Asked a question & 15 & 30 & $50 \%$ \\
3. $\quad$ Wrote the material & 24 & 30 & $80 \%$ \\
4. $\quad \begin{array}{l}\text { Finished the assignment on the } \\
\text { whiteboard }\end{array}$ & 30 & 30 & $100 \%$ \\
5. $\quad$ Finished the assignment by using Plickers & 30 & 30 & $100 \%$ \\
6. $\quad \begin{array}{l}\text { Finished the assignment by using Join } \\
\text { Quizizz }\end{array}$ & 30 & 30 & $100 \%$ \\
\hline
\end{tabular}

This study also used survey interviews to supplement data that have been collected. The format of this interview is an informal conversational interview. Gay \& Mills (2012) states that this format relies entirely upon the spontaneous generation of questions in natural interaction, typically one that occurs as part of ongoing participant observation fieldwork. The research participants may not even realize that they are being interviewed because the conversation appears natural. 
Table 2. Interview Result

\begin{tabular}{llllr}
\hline No. & Interview Indicator & $\begin{array}{l}\text { Number of } \\
\text { Student }\end{array}$ & $\begin{array}{l}\text { Total Number } \\
\text { of Student }\end{array}$ & Percentage \\
\hline 1. & $\begin{array}{l}\text { Not familiar with technology in language } \\
\text { learning }\end{array}$ & 20 & 30 & $67 \%$ \\
2. & Poor internet connection & 25 & 30 & $83 \%$ \\
3. & Positive responds & 30 & 30 & $100 \%$ \\
4. & Repeat activities & 30 & 30 & $100 \%$ \\
5. & Enjoy the learning process & 24 & 30 & $80 \%$ \\
\hline
\end{tabular}

\section{Discussion}

The material has been given based on students' need, the classroom situation, and the development of technology. So the students thought based on what they need to learn, depends on the classroom situation, and doing the exercise and assignment by using technology chosen by teacher that suitable with their condition.

Based on observations, there are significant changes related to the way the material is presented. All of the students took part in doing exercise on the whiteboard, finishing the assignment using join Quizizz and Plickers application. 25\% of the students paying attention, $24 \%$ wrote the material and only $15 \%$ of the students asking questions during the teaching and learning activities.

Interviews were conducted by giving a variety of unstructured questions. Each question given depend on each student's answers. Information obtained from the interview that each student is interested in various teaching methods. Use smartphones in the learning activities increase student interest in learning. Varied teaching methods make students feel at home, especially when learning is presented as interesting as playing games using smartphone. This teaching and learning activity makes students more independent in working on every question given. The use of this method helps them stay abreast of technological developments that are adapted to the situations and conditions of them. This method also improves students' vocabulary achievement. This result is similar to Indah (2015) concluded that the use of ICAM in teaching vocabulary is effective to be implemented in improving the students' vocabulary achievement. Using this method combined face to face classroom instruction, with based activity to create optimal learning achievement agree with Albrecht, (2006) and Bersin (2004).

Information obtained from the interview that each student is interested in various teaching methods. Use smartphones in the learning activities increase student interest in learning. Varied teaching methods make students feel at home, especially when learning is presented as interesting as playing games using smartphone. As we know, most of the students likes to play a game, especially using their smartphone. This teaching and learning activity makes students more independent in working on every question given. The use of this method helps them stay abreast technological developments that are adapted to the situations and conditions of them. 
This result in line with the previous research Sahraini (2015), who claims that in designing a model of teaching and learning of English vocabulary through interactive activities, hopefully, an English teacher can make the students enjoyable and interested in studying English. The teacher must also be creative in using some appropriate approaches, techniques, and games in the process of teaching and learning.

\section{Conclusion}

Based on the results of research and discussion, it can be concluded that the vocabulary teaching process with blended learning can increase and attract students to participate in the teaching and learning process. Also, the use of Plickers and Join Quizizz application can attract students to focus during the teaching and learning process. This is caused by an attractive appearance, and this activity is an activity they have never done before. The design of blended learning method should focus on students' needs, classroom situations, and development of technology.

This study suggests that educators at various levels of education should apply this method by adjusting the situation and conditions of their students. It is worth noting that the need for adequate internet facilities so that students can study independently under the supervision of educators. However, further research is needed to get deeper into the use of the blended learning method for Non-English Language Learners so that it can be more useful to improve the quality of education in Indonesia.

\section{Acknowledgment}

I would like to express my special thanks of gratitude to KEMENRISTEKDIKTI, especially DIRJENRISBANG for their funding support in my research project. I would also like to extend my appreciation to the Rector of Universitas Muhammadiyah Bulukumba and LPPM for providing me with all the facility that was required.

\section{References}

Albrecht, B. (2006). Enriching student experience through blended learning. Research Bulletin, 12, 1-12.

Bersin, J. (2004). The blended learning book: Best practices, proven methodologies, and lessons learned. John Wiley \& Sons.

Gay. L. R., \& Mills, G. E. (2012). Educational Research: Competencies for Analysis and Applications (10th ed.; Christie Robb, ed.). United States: Pearson Education.

Mantyla, K. (2001). Blending e-learning. American Society for Training and Development.

Morris, N. P. (2010). Blended learning approaches enhance student academic performance. Proceedings of Enhancing Learning Experiences in Higher Education: International Conference. Hong Kong University.

Ochoa Alpala, C., \& Roberto Flórez, E. (2011). Blended Learning in the Teaching of English as a Foreign Language: An Educational Challenge. How, 18(1), 154-168.

Indah, O. D. (2015). Applying Integrated Computer Assisted Media (ICAM) in Teaching Vocabulary. Ethical Lingua, 2(1), 118-132.

Pardede, P. (2012). Blended Learning for ELT. JET (Journal of English Teaching), 2(3), 165. https://doi.org/10.33541/jet.v2i3.54

Sahraini. (2015). A Model of Communicative Teaching and Learning of English Vocabulary Through Interactive Activities. Ethical Lingua, 2(1), 1-15. 
Sherli, S., Talis, N., Akib, E., \& Baso, F. A. (2018). The Students' Perception Toward Implementing Blended Learning Method in English Language Teaching (ELT) at the 5th Semester Students of English Education Department ( A descriptive Qualitative Research ). Jurnal Keguruan Dan IImu Pendidikan (JKIP), 5(1), 37-51.

Vasbieva, D. G., Klimova, I. I., Agibalova, E. L., Karzhanova, N. V., \& Bírová, J. (2016). Enhancement of students' vocabulary learning through a blended learning approach. Mathematics Education, 11(5), 1195-1203.

Wallace, M. J. (1982). Teaching vocabulary. Heinemann. 